\title{
Implementation of ICT for Supply Chain Management by the Large and MSME Indian Pharmaceutical Manufacturing Firms
}

\author{
Kanabar KAVITA ${ }^{\star}$, Padake VAISHALI ${ }^{\star \star}$
}

\begin{tabular}{l}
\hline \multicolumn{1}{c}{ A R T I C L E I N F O } \\
\hline Article history: \\
Accepted November 2019 \\
Available online December 2019 \\
\hline JEL Classification \\
M15, M16, L6, L65 \\
Keywords: \\
ICT adoption, SCM, Pharmaceutical \\
Manufacturing Companies, India
\end{tabular}

\begin{abstract}
A B S T R A C T
The information system plays an essential role in success of company's performance. ICT in manufacturing sectors have created simpler processes, increased efficiency and competency all over the world. The present study aims to explore the ICT tools adopted by the Pharmaceutical manafucturing firms in supply chain management. The large, medium and small sized firms located in western region of India was surveyed and investigated their existing status of IT usage, largely prefered software and investment in ICT tools and percentage of cost as per the size of the firms. The finding suggests that all the firms under the study irrespective of their size (large, medium and small) invest in ICT tools for better functioning of the supply chain.
\end{abstract}

(C) 2019 EAI. All rights reserved.

\section{Introduction}

The information system plays an essential role in success of company's performance. ICT in manufacturing sectors have created simpler processes, increased efficiency and competency all over the world. ICT supports the effectiveness of supply chain within and outside the companies. Global manufacturing firms spend heavily on ICT for increasing their efficiencies and quality, thereby complying with regulatory standards. ICT companies offer customized solutions for the industry to successfully work on diverse business models. The ICT Infrastructure consists of hardware and software, which provides data, knowledge, information and interfaces between computers and the various tools and machines on the shop floor. There are numerous literatures available on usage of ICT in supply chain management however the studies in ICT utilisation in the Pharmaceutical Industry are scant. Against this backdrop, the current study attempts to identify successful implementation of ICT and the challenges faced by large and MSME Pharmaceutical manufacturing in Western region of India. The scheme of this paper is; the existing literature is reviewed in the second section; research methodology and research hypothesis is presented in section three; section four reports the data and results. The final section of the study concludes the paper.

\section{Literature Review}

In recent times, studies are focused on internet-based technology that supports SCM. ICT application provides competitive advantage to the firms and adopting ICT in Supply Chain have gained huge importance. Roberts and Mackay (1998) identified the benefits of the ICT adoption. They are reduced lead time, lower SCM costs, improved process and enhancement of relationship with the suppliers. Barut et al. (2002) found more benefits of ICT implementation like fast response to the consumers' requirement, reduced inventories and expenses that are incurred with increase in shipment and/or production.

ICT has an enormous influence on the supply chain management as the latest technologies enable the information to flow rapidly and spreading over all the operations within the organization (Schary and SkjøttLarsen, 2001). The primary role of ICT in supply chains is to generate visibility in the processes, reduce the inventories and cycle time and improved distribution channels efficiency (Zhang et al., 2011; Vanpouckle et al., 2009). The enhanced level of productivity can also be associated with the ICT adoption in supply chain management of the firm (Cainelli et al., 2004).

The extent of ICT adoption may differ for large and small firms. In a study by Pokharel (2005), large organizations are increasingly influenced to adopt ICT and distinguish the barriers to adoption differently than smaller organizations. The large organizations have successfully adopted ICT techniques and shown an

\footnotetext{
${ }^{\star},{ }^{\star \star}$ K.J. Somaiya Institute of Management Studies \& Research, India. E-mail address: vaishali.padake@somaiya.edu (V. Padake - Corresponding author)
} 
optimistic attitude towards it. It was noticed that the ICT expenses are either treated as overheads or integrated with some other heading in the statement making it difficult to obtain the correct level of ICT cost.

Many studies agreed that the ICT adoption brings positive effects to the organisation by decline in the cost of coordination and it may lead to the supply chain inefficiencies. These inefficiencies can be inventory buffers, under-utilised capacity, obsolescence of products or lost sales. The studies by Pokharel (2005) and Kilpala et. al. (2005) stressed the prominent role of other factors in increasing the internal efficiency such as operational cost and inventory management. This study also highlighted high investment costs, ineffective employee training and un-awareness of the ICT benefits as few of the other barriers to ICT adoption.

The review of the earlier research literature sheds light on the benefits of ICT adoption in SCM, issues related to ICT adoption and perception of ICT adoption by the large and small companies.

\section{Research Design and Method}

This section is divided into four parts. They are
1. Background of the research
2. Categorization of the firms
3. Research question, aim of the study and methodology
4. Hypothesis development and tools used for analysis

\subsection{Context of the Research: Indian Pharmaceutical manufacturing companies}

The Indian Pharmaceutical Sector that has witnessed a significant expansion recently is very diverse. This Industry is multifaceted due to its huge size and presence of complex processes and technologies. The administration and development of its distribution system is also very expensive. All of this leads to lots of organizational and management challenges (Dwarakanadha et al. 2010). The leading 250 pharmaceutical companies dominate $70 \%$ of the market with market leader having $7 \%$ stake in the market. With respect to other industries in India, the Pharmaceutical industry is one of the innovative and has been adapting itself more to the strategic market trends and market demands.

The Indian pharmaceutical industry has witnessed lot of changes and has completely altered itself to be the world leader in manufacturing of generic drugs. Indian pharmaceutical industry is fragmented and consists of number of small, medium and large enterprises (Buzzelli, 2006). The Government of India encourages manufacturing by Small and Medium Sized Enterprises (SMEs) by reserving some pharmaceuticals items to be exclusively manufactured by them. The other pharmaceutical manufacturing companies have entered into contract manufacturing and R\&D with other companies (Timonen et al. 2010)

As per the IBEF Report 2018, the Indian pharmaceutical sector contributes around 3.1 to 3.6 per cent to the global pharmaceutical production in terms of value and in terms of volume it is 10 per cent of the global production. It is estimated that the Indian pharmaceutical market size would increase to US\$100 billion by 2025, and the major drivers of growth will be increase in consumer spending, rapid urbanization, and raising healthcare insurance among other reasons. Pharma sector's revenues are expected to grow by 9 per cent year-on-year through fiscal 2020. (IBEF, 2018)

\subsection{Categorization of the firm}

In this study, the classification of MSMEs is as per Indian government's categorization based on business turnover, wherein companies with revenue of ₹ 5 crore or less will be called as a micro enterprise. The companies that reports turnover between ₹ 5 crore and ₹ 75 crore will be classified as the small companies. The medium-sized enterprises are the one with the revenue between $₹ 75$ crore and ₹ 250 crore. The company with the turnover of above ₹ 250 crore would be considered as a large-scale enterprise in India. The current study focuses on Large, medium and small companies while micro enterprises are not considered as ICT investments in such companies are very low.

\subsection{Research question, objectives and methodology}

The literature based on ICT adoption in SCM for developed and developing countries are available while the studies in the Indian Pharmaceutical Manufacturing Companies are scant. The current study aims to fill this gap by exploring the existing usage of ICT in inbound supply chain of Pharmaceutical manufacturing companies in western region of India. The research questions proposed by the study are:

What is the current status of the ICT utilisation in Supply Chain of Pharmaceutical Manufacturing companies and challenges faced by the organizations in utilizing the ICT tools? Does the firm size affect the level of investments in usage of ICT?

To investigate the answer to the above question, survey of 100 companies comprising 40 Small Scale, 47 Medium Scale and 13 large Scale from Mumbai, Navi Mumbai and Thane was conducted. The scale to measure the ICT status of the organization was adopted from the Tanner, Wölfle, Schubert \& Quade (2008). 


\subsection{Hypothesis development and tools used for analysis}

The above mentioned research questions stated were investigated by understanding the usage of ICT, software used, factors stimulating ICT and the percentage cost of ICT to the total company cost. The hypothesis was formulated using these constructs and confirmed using the data collected in the survey. The study explores the relationship between the ICT tools utilized by the company and the overall extent of ICT integration with its supply chain associates. The study tests the hypothesis that there is correlation between the percentage of ICT cost to the total company costs and the firm size. The tool for analysis used was cross tabulation to find the association.

\section{Results and Discussion}

The findings of the ICT tools adopted by the firms under survey are reported in table 1 . The results shows that the Telephone, Fax and Email, Internet, company website and ERP are largely used while the Wireless LAN, EDI, Mobile and RFID are very less used ICT tools in the surveyed Pharmaceutical manufacturing companies.

Table 1. Usage of ICT

\begin{tabular}{|l|l|l|l|}
\hline ICT Tools & Per cent & ICT Tools & Per cent \\
\hline Tel/Fax & $14.50 \%$ & Wireless LAN & $1.60 \%$ \\
\hline Internet & $13.70 \%$ & LAN & $11.10 \%$ \\
\hline E mail & $14.50 \%$ & CRM & $3.20 \%$ \\
\hline Company Website & $13.60 \%$ & RFID & $1.90 \%$ \\
\hline ERP & $13.10 \%$ & Certified E mail & $4.10 \%$ \\
\hline EDI & $1.30 \%$ & Mobile & $3.00 \%$ \\
\hline Barcode & $4.30 \%$ & Total & $100.00 \%$ \\
\hline
\end{tabular}

Table 2 shows the software used by pharmaceutical organizations. The most common software used was Sales management software followed by import-export software and inventory management software and ERP.

Table 2. Software used

\begin{tabular}{|l|l|}
\hline Software & Per cent \\
\hline Quality Management & $10.70 \%$ \\
\hline Transport Simulation/Optimization & $7.47 \%$ \\
\hline Transport Management & $8.48 \%$ \\
\hline Warehouse Management & $10.51 \%$ \\
\hline Import-Export & $14.34 \%$ \\
\hline Sales Management & $16.57 \%$ \\
\hline CRM & $4.44 \%$ \\
\hline Inventory Management & $14.55 \%$ \\
\hline ERP & $12.93 \%$ \\
\hline Total & $100.00 \%$ \\
\hline
\end{tabular}

Table 3 indicates the factors that stimulate ICT usage in organization. Higher in-company integration is the major factor stimulating the ICT usage in the surveyed organizations followed by improving company competitiveness and improving information exchange with customers as the stimulating factor for ICT usage.

Table 3. Factors stimulating ICT usage

\begin{tabular}{|l|l|}
\hline Factors Stimulating ICT & Percent \\
\hline Higher in-company integration & $25.69 \%$ \\
\hline Customer Satisfaction Improvement & $6.73 \%$ \\
\hline
\end{tabular}




\begin{tabular}{|l|l|}
\hline Factors Stimulating ICT & Percent \\
\hline Improve information exchange with customers & $19.27 \%$ \\
\hline Customer base Enlargement & $8.56 \%$ \\
\hline Increase company competitiveness & $21.71 \%$ \\
\hline Improve company's brand perception & $18.04 \%$ \\
\hline Total & $100.00 \%$ \\
\hline
\end{tabular}

To find whether the firm size affect the level of investments in ICT adoption, percentage of ICT cost to the total expenditure of the surveyed companies was calculated. Table 4 reports the number of companies and their share of ICT costs in total company cost.

Table 4. Percentage of ICT cost to the total company cost

\begin{tabular}{|l|l|}
\hline $\begin{array}{c}\text { \% of ICT cost to } \\
\text { Total cost }\end{array}$ & Companies \\
\hline Less Than $0.5 \%$ & 5 \\
\hline $0.5 \%$ to $1 \%$ & 47 \\
\hline $1 \%$ to $3 \%$ & 24 \\
\hline $3 \%$ to $10 \%$ & 17 \\
\hline More Than $10 \%$ & 7 \\
\hline Total & 100 \\
\hline
\end{tabular}

Among the respondents, 47 companies reported 0.5 to 1 percent of the total company costs were spent on ICT tools. There were 24 firms spent 1 to 3 percent of the total expenditure on ICT tools. Firms that spent between 3 and 10 percent of the total expenditure on ICT tools were 17 and only 7 firms spent more than $10 \%$ of the total expenditure on ICT tools. Only 5 firms among the respondents spent less than 0.5 percent of the total expenditure on ICT tools.

Table 5 reports the cross tabulation of percentage of ICT costs to the total company cost for large, medium and small size firm.

Table 5. Cross tabulation: Percentage of ICT Costs to the total expenditure

\begin{tabular}{|c|c|c|c|c|c|c|c|c|}
\hline & \multicolumn{5}{|c|}{ Percentage of ICT Costs to the total expenditure } & \multirow[b]{2}{*}{ Total } \\
\hline & & & $\begin{array}{r}\text { Less Than } \\
0.5 \% \\
\end{array}$ & $\begin{array}{r}0.5 \% \text { to } 1 \\
\% \\
\end{array}$ & $\begin{array}{r}1 \% \text { to } 3 \\
\% \\
\end{array}$ & $\begin{array}{r}3 \% \text { to } 10 \\
\% \\
\end{array}$ & $\begin{array}{r}\text { More Than } \\
10 \% \\
\end{array}$ & \\
\hline \multirow{9}{*}{ Scale } & \multirow{3}{*}{$\begin{array}{l}\text { Small Scale } \\
\text { Organizations }\end{array}$} & Count & 3 & 28 & 5 & 4 & 0 & 40 \\
\hline & & Expected Count & 2.0 & 18.8 & 9.6 & 6.8 & 2.8 & 40.0 \\
\hline & & $\%$ within Scale & $7.5 \%$ & $70.0 \%$ & $12.5 \%$ & $10.0 \%$ & $.0 \%$ & $100.0 \%$ \\
\hline & \multirow{3}{*}{$\begin{array}{l}\text { Medium Scale } \\
\text { Organizations }\end{array}$} & Count & 1 & 15 & 14 & 10 & 7 & 47 \\
\hline & & Expected Count & 2.4 & 22.1 & 11.3 & 8.0 & 3.3 & 47.0 \\
\hline & & $\%$ within Scale & $2.1 \%$ & $31.9 \%$ & $29.8 \%$ & $21.3 \%$ & $14.9 \%$ & $100.0 \%$ \\
\hline & \multirow{3}{*}{$\begin{array}{l}\text { Large Scale } \\
\text { Organizations }\end{array}$} & Count & 1 & 4 & 5 & 3 & 0 & 13 \\
\hline & & Expected Count & .7 & 6.1 & 3.1 & 2.2 & .9 & 13.0 \\
\hline & & $\%$ within Scale & $7.7 \%$ & $30.8 \%$ & $38.5 \%$ & $23.1 \%$ & $.0 \%$ & $100.0 \%$ \\
\hline \multirow{3}{*}{\multicolumn{2}{|c|}{ Total }} & Count & 5 & 47 & 24 & 17 & 7 & 100 \\
\hline & & Expected Count & 5.0 & 47.0 & 24.0 & 17.0 & 7.0 & 100.0 \\
\hline & & \% within Scale & $5.0 \%$ & $47.0 \%$ & $24.0 \%$ & $17.0 \%$ & $7.0 \%$ & $100.0 \%$ \\
\hline
\end{tabular}

Maximum number of small and medium firms spent between 0.5 percent and 1 percent of their expenditure on ICT costs. There were 28 small firms out of 40 companies and 15 companies out of 47 
medium sized companies spent between 0.5 and 1 percent of their expenditure on ICT costs. It was found that the large organizations spent between $1 \%$ and $3 \%$ of their total company costs on ICT costs (5 companies out of 13 companies).

Table 6. Chi-Square Tests

\begin{tabular}{|l|l|l|l|}
\hline & Value & df & $\begin{array}{l}\text { Asymp. Sig. (2- } \\
\text { sided) }\end{array}$ \\
\hline Pearson Chi-Square & 22.79 & 8 & .004 \\
\hline
\end{tabular}

Table 6 reports the results of the Chi-square test. The calculated value of Chi-square test at 8 degrees of freedom was 22.798. The Asymp. Sig (2-sided) P-Value is 0.004 and hence it is significant at 5\%. It can be concluded that there is association between category of the organisation and percentage of ICT Costs to the total company costs.

Table 7 Symmetric Measures

\begin{tabular}{|l|l|l|l|}
\hline \multicolumn{2}{|c|}{} & Value & Approx. Sig. \\
\hline \multirow{2}{*}{ Nominal by Nominal } & Phi & .477 & .004 \\
\cline { 2 - 4 } & Cramer's V & .338 & .004 \\
\hline
\end{tabular}

Table 7 reports the Symmetric Measures. To measure the strength of association between these two variables, the Cramer's V was considered instead of Phi value. The Phi value is generally used to measure the strength of the association between two variables, each of which has only two categories (it applies to $2 \mathrm{X} 2$ nominal tables only). Normally Phi or Cramer Value should be greater than $50 \%$. If it is less than $50 \%$ it is weak relationship. The value of Cramer's V is 0.338 which shows the weak association between category of the organization and percentage of ICT Costs to the total company costs. The weak association indicates that ICT utilisation is not limited to large firms only. Even Small and medium firms invest adequately in ICT tools. The study finds that almost all the companies surveyed uses ICT tools for smooth functioning of the supply chain.

\section{Conclusion}

This section summarises the research findings, enlists limitations and potential future research.

With rapid implementation of the ICT tools in supply chain management, very little attention was given to the ICT adaptation in the Pharmaceutical manufacturing companies in India. The study surveyed 100 small, medium and large firms and investigated ICT usage and challenges in effective implementation in inbound SCM. It was found that the Telephone, Fax and Email, Internet, company website and ERP are largely preferred. The most common software used was Sales management software followed by import-export software and inventory management software and ERP. The integration of the ICT tools with the supply chain companies was the major motivating reason for the company to adopt the ICT tools. It was also observed that large companies spend more on updating and maintenance of the ICT tools. However SMEs also tend to invest equally well on upgradation and adopting the ICT tools.

\subsection{Limitation}

It is an exploratory study and hence subject to certain limitations. The sample size is 100 and the companies were based out of western region of India only. Since the study incorporated the Indian Pharmaceutical manufacturing firms only, the results cannot be generalised to the other sectors.

\subsection{Future scope}

The study can replicate the relationships tested in this study in different manufacturing industries, as it would help to clarify the conditions for generalizations in other parts of the country and Asia. The longitudinal data would also improve an understanding of the mechanisms influencing different aspects of inbound supply chain.

\section{References}

1. Barut, M., Faisst, W. \& Kanet, J. J. (2002). Measuring supply chain coupling: an information system perspective. European Journal of Purchasing \& Supply Management, Vol. 8, pp. 161-171.

2. Buzzelli A., (2006), Impact of generic substitution on pharmaceuticals prices and expenditures in OECD countries, Journal of Pharmaceutical Finance, Economics and Policy, 15(1), pp 41-63. 16.

3. Cainelli, G., Evangelista, R., Savona, M. (2004). The impact of innovation on economic performance in services, The Service Industries Journal, 24(1), 116-130.

4. Indian brand equity foundation, 2018 report (link: https://www.ibef.org/archives/detail/b3ZlcnZpZXcmMzcxMDYmOTA)

5. Kilpala, H., Solvang, W.D., Widmark, J., Bagaeva, A., Tuohinto, P. (2005). Analysis of ICT use in the Barents region: research findings from logistics service providers and forest industry. Sustainable Transport in the Barents Region (STBR), Publications No.11.,2010

6. Pokharel, S. (2005), "Perception on information and communication technology perspectives in logistics", Journal of Enterprise Information Management, Vol. 18 No. 2, pp. 136-149. 
7. Roberts, B. \& Mackay, M. (1998). IT supporting Supplier Relationships: The Role of Electronic Commerce. European Journal of Purchasing and Supply Management, 4, 75-184.

8. Satyanarayana T. D., Reddy P., Swarnalatha, D., Purushothaman, M. (2010). Enforcement of Intellectual Property Rights: International and National Obligations and Practical Challenges in Pharmaceuticals Sector. JITPS, 1(4), pp 186- 190.

9. Schary, P., Skjøtt-Larsen, T. (2001): Managing the Global Supply Chain, 2nd edition, Copenhagen Business School Press, Copenhagen.

10. Tanner, C., Wölfle, R., Schubert, P., \& Quade, M. (2008). Current trends and challenges in electronic procurement: an empirical study. Electronic Markets, 18(1), 6-18.

11. Timonen, J., Bengtström, M., Karttun, P., Karttun, A., Riitta. (2010). The impact of generic substitution on the activities of pharmaceutical companies - a survey from the companies' perspective one year and five years after the introduction of generic substitution in Finland. BMC clinical pharmacology. DOI:10.1186/1472-6904-10-15

12. Vanpoucke, E., Boyer, K.K., Vereecke, A. (2009). Supply chain information flow strategies: an empirical taxonomy. International Journal of Operations \& Production Management, 29(12), 1213-1241.

13. Zhang, Q. Y. (2001). Technology infusion enabled value chain flexibility: A learning and capability-based perspective. Doctoral dissertation, University of Toledo, Toledo, $\mathrm{OH}$

14. Zhang X., van Donk D.P., van der Vaart T. (2011). Does ICT influence supply chain management and performance? A review of surveybased research. International Journal of Operations \& Production Management, 31(11), 1215-1247. 